\title{
The role of salivary contents and modern technologies in the remineralization of dental enamel: a review [version 1; peer
}

\section{review: 3 approved]}

\section{Imran Farooq (D), Amr Bugshan (iD)}

Department of Biomedical Dental Sciences, College of Dentistry, Imam Abdulrahman Bin Faisal University, Dammam, 31441, Saudi Arabia

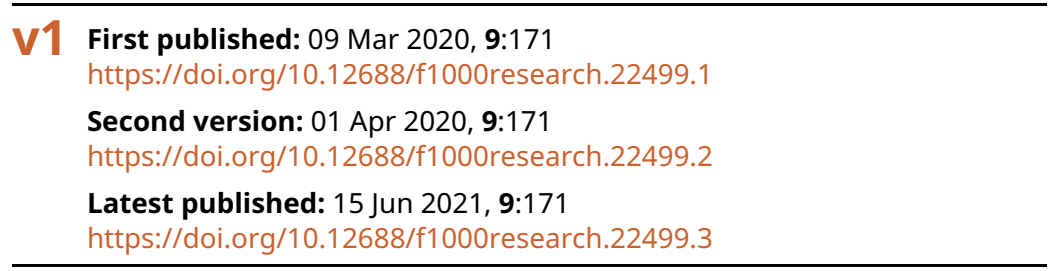

\section{Abstract}

Human enamel once formed cannot be biologically repaired or replaced. Saliva has a significant role in remineralization of dental enamel. It not only has a buffering capacity to neutralize the oral cavity's low pH generated after acidic encounters, but also acts as a carrier of essential ions, such as fluoride, calcium and phosphate, which have a positive role in enamel's remineralization. This review discusses how salivary contents, like proteins and enzymes, have a natural role in enamel's mineralization. In addition, the presence of ions, such as fluoride, calcium and phosphate, in saliva further enhances its capability to remineralize the demineralized enamel surface. The review further examines modern innovative technologies, based on biomimetic regeneration systems, including dentin phosphoproteins, aspartate-serine-serine, recombinant porcine amelogenin, leucine-rich amelogenin peptide and nanohydroxyapatite, that promote enamel remineralization. Fluoride boosters like calcium phosphates, polyphosphates, and certain natural products can also play an important role in enamel remineralization.

Keywords

Saliva, Enamel, Remineralization, Fluoride, Calcium Phosphate

\begin{tabular}{|c|c|c|c|}
\hline \multicolumn{4}{|c|}{ Open Peer Review } \\
\hline \multicolumn{4}{|c|}{ Approval Status } \\
\hline & 1 & 2 & 3 \\
\hline \multicolumn{4}{|l|}{ version 3} \\
\hline (revision) & & view & \\
\hline 15 Jun 2021 & & $\mathrm{~A}$ & \\
\hline version 2 & & 1 & \\
\hline (revision) & $\checkmark$ & $\begin{array}{l}\text { view } \\
\text { val }\end{array}$ & $\begin{array}{c}\checkmark \\
\text { view }\end{array}$ \\
\hline 01 Apr 2020 & 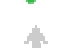 & s & 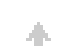 \\
\hline version 1 & $\checkmark$ & $\checkmark$ & $\checkmark$ \\
\hline 09 Mar 2020 & view & view & view \\
\hline
\end{tabular}

1. Rizwan Ullah, Jinnah Sindh Medical University, Karachi, Pakistan

2. A. Thirumal Raj iD), Sri Venkateswara Dental College and Hospital, Chennai, India

3. Dr. Shakeel Abbas Kazmi, University of Dundee, Dundee, UK

Any reports and responses or comments on the article can be found at the end of the article. 
Corresponding author: Imran Farooq (drimranfarooq@gmail.com)

Author roles: Farooq I: Conceptualization, Data Curation, Formal Analysis, Investigation, Methodology, Project Administration, Resources, Software, Supervision, Validation, Visualization, Writing - Original Draft Preparation, Writing - Review \& Editing; Bugshan A: Conceptualization, Data Curation, Formal Analysis, Investigation, Methodology, Project Administration, Resources, Software, Supervision, Validation, Visualization, Writing - Original Draft Preparation, Writing - Review \& Editing

Competing interests: No competing interests were disclosed.

Grant information: The author(s) declared that no grants were involved in supporting this work.

Copyright: (c) 2020 Farooq I and Bugshan A. This is an open access article distributed under the terms of the Creative Commons Attribution License, which permits unrestricted use, distribution, and reproduction in any medium, provided the original work is properly cited.

How to cite this article: Farooq I and Bugshan A. The role of salivary contents and modern technologies in the remineralization of dental enamel: a review [version 1; peer review: 3 approved] F1000Research 2020, 9:171

https://doi.org/10.12688/f1000research.22499.1

First published: 09 Mar 2020, 9:171 https://doi.org/10.12688/f1000research.22499.1 


\section{Introduction}

Dental enamel is a calcified tissue that forms the outer protective covering of the anatomical crown of a tooth ${ }^{1}$. Enamel once formed cannot be biologically repaired or replaced ${ }^{2}$. The oral cavity continuously goes through cycles of demineralization and remineralization $^{3}$. Loosing minerals from the tooth after an acidic encounter is called demineralization, whereas restoration of these minerals back into the tooth structure is called remineralization ${ }^{4}$. During demineralization, the enamel surface becomes rough and rugged upon acidic encounter. Thus throughout the life of a tooth, there are enamel demineralization/remineralization cycles that dictate the extent of mineral balance and tissue integrity or degradation ${ }^{3}$. Human saliva has a buffering role and acts as a carrier of essential ions that can bring a constructive change in the structure of enamel, promoting remineralization ${ }^{5}$.

This review is aimed at providing an overview of enamel structure and an in-depth insight on its mineralization mechanism carried out by salivary contents. Literature published in the past 35 years (1985-2020) was explored on "Google Scholar" and "PubMed" search engine using the key words "saliva", "enamel remineralization", "salivary contents", "fluoride and enamel", and "calcium phosphate and enamel". The search retrieved 1000+ hits and 500 relevant articles were then studied in detail. Conference abstracts, poster presentations, and all articles published in a language other than English were excluded from this review. A final selection of 65 pertinent articles was made and these were then included in this study for review.

\section{Structure of dental enamel}

Dental enamel is composed of $96 \%$ inorganic material, 3\% water, and $1 \%$ organic matrix ${ }^{6}$. The inorganic component of dental enamel is hydroxyapatite (HAP) crystal and human enamel is a hard, acellular, and avascular tissue ${ }^{1}$. Being acellular, it cannot be automatically replaced or repaired if damaged $^{2}$. However, its very highly mineralized nature makes it extremely resistant to destruction? ${ }^{7}$. Enamel's high mineral content also makes it susceptible to demineralization by acids formed by bacteria in the mouth, which leads to dental caries ${ }^{3}$.

Tooth enamel is an intricate structure and requires a keen sense of three-dimensional geometry to appreciate it. Early micro-anatomical descriptions are incomplete and reflected the restrictions of light microscopy. Only after the advent of modern techniques using transmission and scanning electron microscopy, was the more complex structure of enamel revealed. Enamel's composition includes fiber-like mineralized crystals and a small proportion of water and proteins that clamp the mineralized fibers with each other ${ }^{8}$. This arrangement of mineralized and non-mineralized components of enamel, disperses the forces passing through teeth and in this manner shields them from fractures ${ }^{4}$. Enamel is composed of discrete basic units called Enamel Rods (formerly enamel prisms), each surrounded by a rod sheath with these packed together and embedded in an inter-rod (inter-prismatic) substance ${ }^{9}$. Ameloblasts elaborate and secrete the enamel protein matrix that is subsequently mineralized by the addition of calcium phosphate crystallites $^{10}$. When fully differentiated, ameloblasts are tall columnar cells fully equipped for protein synthesis ${ }^{11}$.
The secretory end of the cell develops a projection (Tome's process) through which the protein matrix and crystallites are laid down ${ }^{12}$. The appearance of the inter-rod (inter-prismatic) substance and rod sheath at a light microscope level is due to the changes in crystallite orientation as they are laid down by ameloblasts $^{13}$. The main body of the enamel $\operatorname{rod}$ is $\sim 5 \mu \mathrm{m}$ in diameter but towards the enamel surface, the diameter is greater ${ }^{14}$. The number of ameloblasts that form the enamel are thought to remain constant for each tooth ${ }^{15}$. At the beginning and end of amelogenesis, Tome's process is absent at the secretory end of ameloblasts and unstructured enamel (rod-less/prism-less) is produced ${ }^{16}$. This prism-less enamel varies in thickness but there is a general agreement that prism-less enamel is composed of HAP crystals that are arranged parallel to one another and perpendicular to the enamel's surface ${ }^{17}$.

It is quite a well-established fact that fluoride helps in the prevention of dental caries $^{18}$. Fluoride has remained under extensive investigations because of its effects on the structure and properties of tooth minerals ${ }^{19}$. Ionic substitution is a common phenomenon in the oral cavity and two major stake holders are enamel and saliva ${ }^{20}$. The carbonate ion can replace hydroxyl or phosphate ions, magnesium can replace calcium, and fluoride can replace hydroxyl ions in the crystal lattice $^{3}$. These ionic substitutions have a significant influence on the behavior of apatite including its solubility ${ }^{21}$. It is well-known that fluoride in the saliva (when it comes in contact with enamel) replaces the hydroxyl ion in the apatite crystal structure thus changing HAP into fluorapatite, which is more resistant to acidic attacks ${ }^{22}$. Therefore, understanding human body glands, particularly salivary glands, prior to going into details on the influence of salivary contents on remineralization of enamel becomes necessary.

\section{Classification of glands and types of salivary glands}

A gland is an organ that synthesizes a secretion for release and two major types of glands found in the human body are exocrine and endocrine glands ${ }^{23}$. Exocrine glands are those which lack a duct system and secrete their products through basal lamina into the bloodstream to regulate the body (for example, salivary and sweat glands $)^{24}$. Endocrine glands possess a duct system and discharge their products into the ducts, which then lead them into the outer environment (for example, pituitary, thyroid and adrenal glands ${ }^{24}$. A salivary gland is an organ that releases a secretion in the oral cavity, and it is further classified into major and minor types ${ }^{25}$. Major salivary glands are situated at a distance from the oral mucosa but are connected to it through extra glandular ducts ${ }^{26}$. Minor salivary glands reside in the mucosa or sub mucosa and can open directly inside the oral cavity ${ }^{27}$. The three major paired salivary glands in humans are parotid, submandibular, and sublingual glands ${ }^{28}$. Among the minor salivary glands, the important ones are von Ebner, Weber, buccal, labial, and palatal glands ${ }^{29}$.

\section{Role of saliva and its contents in remineralization of dental enamel}

Human saliva is comprised of numerous contents and therefore has various functions. Saliva is a fluid that protects the mouth against harmful microorganisms and irritants ${ }^{30}$. It not 
only lubricates the oral tissues but also helps in various other functions, such as speech, mastication and swallowing, as well as protection of the teeth and oral tissues ${ }^{31}$. The ability of saliva to remineralize tooth enamel is dependent on various factors, discussed below.

\section{Buffering capacity}

The buffering capacity of saliva displays an imperative role in maintaining the level of $\mathrm{pH}$ in both saliva and plaque, therefore helping in neutralizing the effects of acid exposure ${ }^{5}$. The three buffer systems present in the saliva are carbonic acid/bicarbonate system (the most important), phosphate system, and protein system ${ }^{32}$. The breakdown of proteins by bacterial originated urease to urea and ammonia aids plays a role in maintaining a neutral $\mathrm{pH}$ in oral cavity ${ }^{33}$. The intake of certain supplemental hormones, like estrogen and progesterone, could also lead to an improvement in salivary buffering capacity in individuals ${ }^{33}$.

\section{Salivary proteins}

Proteins are part of the normal anatomy of human saliva and some salivary proteins, such as proline rich proteins, statherin and histatins, have an affinity for enamel surfaces and thus help remineralization by increasing local calcium concentration ${ }^{34}$. Other proteins, e.g. cathelicidin LL3, have an antimicrobial function; histatins are antibacterial, and alpha-defensin HNP1-3 are antiviral in function ${ }^{35}$. Certain proteins, like lactoferrin, can prevent Streptococcus mutans growth, as they can isolate iron from the oral environment, which is vital for bacterial metabolism ${ }^{33,36}$.

\section{Salivary enzymes}

Lysozyme enzyme is found in humans in serum, amniotic fluid, and saliva ${ }^{37}$. Lysozyme found in saliva helps in the lysis of bacterial cells ${ }^{31}$ and is especially potent against gram-positive bacteria $^{38}$. Lysozyme is also believed to have a part in prevention of bacterial aggregation and adherence, thus providing an opportunity for bacterial autolysins, which can then destroy cell walls of bacteria ${ }^{39}$. Salivary peroxidase enzyme preserves oral health by preventing build-up of hydrogen peroxide and deactivates carcinogenic compounds ${ }^{37}$.

\section{Salivary fluoride ions}

At a normal $\mathrm{pH}$, saliva is supersaturated with calcium and phosphate ions, therefore, demineralization does not take place ${ }^{40}$. Acids of bacterial origin and those coming from food or drinks tend to shift the equilibrium towards the mineral loss ${ }^{3}$. The phosphate concentration of saliva is reduced and at $\mathrm{pH} 5.5$, saliva no longer remains supersaturated and demineralization initiates. Saliva acts as a remineralizing agent and as a delivery vehicle of ions, like fluoride, which can then incorporate in the tissues ${ }^{41}$. It should be noted however, that complete substitution of fluoride with hydroxyl does not occur, but even a limited replacement is able to significantly reduce the incidence of dental caries and initiate remineralization ${ }^{33}$. The presence of partially demineralized crystallites is a pre-requisite for remineralization as these crystallites then act as nuclei for mineral deposition ${ }^{42}$. Fluoride in saliva could have three major roles; prevention of demineralization, promotion of remineralization, and interfering with growth of bacteria ${ }^{43}$. Dental caries starts with a white spot lesion (WSL) and these lesions can be reversed with appropriate fluoride therapy ${ }^{44}$. However recently, Dai et al. have reported that only fluoride therapy (FT) could be insufficient for reversal of WSLs and a combination of FT with fluoride varnish and FT with casein phosphopeptide-amorphous calcium phosphate (CPP-ACP) application could be more effective in remineralization ${ }^{45}$.

\section{Salivary calcium and phosphate ions}

Both calcium and phosphate ions are required by fluoride to promote the natural remineralization process of enamel ${ }^{46}$. The water content present in enamel facilitates influx of acids and efflux of minerals thus causing demineralization ${ }^{20}$. It has been previously reported that during the demineralization process, calcium is released before phosphate ions; therefore using a calcium-based product could suppress the demineralization process effectively ${ }^{5}$. Due to the use of increased amounts of fluoride in dentifrices, concerns regarding its toxicity were raised and casein phosphopeptides (calcium and phosphate-based products) have been introduced ${ }^{47}$. For an equal rate of supersaturation, an ideal rate of enamel remineralization can be attained with a calcium/phosphate $(\mathrm{Ca} / \mathrm{P})$ ratio of $1.6^{48}$. In the plaque, the $\mathrm{Ca} / \mathrm{P}$ ratio is $\sim 0.3$, so supplemental calcium will enhance remineralization of ename $^{48}$. Salivary pellicle starts forming on the tooth surface almost immediately post-absorption of proteins and peptides onto the enamel's surface ${ }^{49}$. Calcium binding peptides attract free calcium ions in the saliva and thus act as a pool for calcium ions in the pellicle ${ }^{50}$. In addition, diffusion of calcium ions through the pellicle inside the enamel's surface takes place easily and this regulates the remineralization process ${ }^{51}$. Calcium phosphate embedded in salivary pellicle has a high solubility (almost ten times more than calcium phosphate in tooth mineral); therefore, it serves as a sacrificial mineral post-acidic challenge instead of calcium phosphate present in the tooth structure, preventing demineralization ${ }^{52}$.

\section{Recent advances in enamel remineralization therapies}

There have been many recent innovative advances in systems that act through saliva to promote enamel remineralization, but that do not depend on fluoride therapies ${ }^{53}$. Philip divided these systems into two categories: (i) biomimetic regeneration technologies; and (ii) systems that boost fluoride effectiveness ${ }^{53}$. In the first category, the most important is tooth regeneration via dentin phosphoprotein (DPP). It has been shown previously that DPP has the ability to remineralize the tooth surface when it is present in a solution containing calcium and phosphate, just like saliva ${ }^{54}$. Many new systems have been derived based on DPP and among them the most active in promoting remineralization is aspartate-serine-serine (8DSS) ${ }^{55}$. Application of 8DSS to the enamel surface does not only prevent leaching of ions from the enamel surface, but also promotes binding of calcium and phosphate ions from the saliva ${ }^{53}$. Amelogenin is an important protein that regulates the growth and maturation of enamel crystals in newly formed enamel matrix $^{15}$. This protein is absent in mature enamel, meaning 
it cannot regenerate ${ }^{56}$. Modern systems, such as recombinant porcine amelogenin (rP172) and leucine-rich amelogenin peptide, stabilize calcium phosphate to enhance crystal formation and direct mineral growth respectively ${ }^{57,58}$. Nanohydroxyapatite is another bioactive material that can promote enamel remineralization ${ }^{53}$. As these particles are very small (nano-sized), they bind strongly to the enamel surface and fill up the gaps and holes in the enamel surface to repair it ${ }^{53,59}$.

In the second category, which are also known as fluoride promoters, many modern systems are available ${ }^{53}$. The most significant are calcium phosphate based systems and among them, the most important is $\mathrm{CPP}-\mathrm{ACP}^{60}$. CPP-ACP particles are readily soluble in saliva and thus localize in plaque and act as a reservoir of calcium and phosphate ions ${ }^{61}$. Upon an acidic encounter, they release these ions to promote remineralization and inhibit demineralization ${ }^{61}$. Another material to boost enamel remineralization is bioactive glass, which is based on calcium sodium phosphosilicate composition ${ }^{62}$. It dissolves in aqueous solution to release sodium, calcium, and phosphate ions in the saliva, to which they interact, leading to deposition of a layer of HAP on the enamel's surface ${ }^{63}$. Another major system in the second category is polyphosphate-based systems and among them the most essential is sodium trimetaphosphate (STMP) ${ }^{64}$.
STMP not only promotes remineralization, but also inhibits its demineralization ${ }^{64}$. Some other natural products, such as thymoquinone, have shown good capability in promoting enamel remineralization in vitro $^{65}$, but data on its in vivo effectiveness is still anticipated ${ }^{65}$.

\section{Conclusion}

Saliva contains many important substances and also acts as a transporter of many important ions, such as calcium, phosphate and fluoride, which are essential for the promotion of remineralization. Pathogenicity of dental erosion and caries is directly influenced by the buffering capacity and contents of saliva. Saliva helps to maintain a constant reservoir of ions that help to neutralize the $\mathrm{pH}$ and prevent demineralization. Modern innovative technologies, for example biomimetic regeneration technologies, including dentin phosphoproteins, aspartate-serine-serine, recombinant porcine amelogenin, leucinerich amelogenin peptide and nano-hydroxyapatite, promote enamel remineralization. Fluoride boosters, like calcium phosphates, polyphosphates and natural products, also play an important role in enamel remineralization.

\section{Data availability}

No data are associated with this article.
1. Lacruz RS, Habelitz S, Wright JT, et al: Dental enamel formation and implications for oral health and disease. Physiol Rev. 2017; 97(3): 939-993. PubMed Abstract | Free Full Text

2. Angelova Volponi A, Zaugg LK, Neves $\mathrm{V}$, et al:: Tooth repair and regeneration Curr Oral Health Rep. 2018; 5(4): 295-303.

PubMed Abstract | Publisher Full Text | Free Full Text

3. Abou Neel EA, Aljabo A, Strange A, et al.: Demineralization-remineralization dynamics in teeth and bone. Int $J$ Nanomedicine. 2016; 11: 4743-4763. PubMed Abstract | Publisher Full Text | Free Full Text

4. AlShehab AH, AlHazoom AA, Alowa MH, et al:: Effect of bristle stiffness of manual toothbrushes on normal and demineralized human enamel-An in vitro profilometric study. Int J Dent Hyg. 2018; 16(2): e128-e132.

PubMed Abstract | Publisher Full Text

5. Buzalaf MA, Hannas AR, Kato MT: Saliva and dental erosion. J Appl Oral Sci. 2012; 20(5): 493-502.

PubMed Abstract | Publisher Full Text | Free Full Text

6. Xu C, Yao X, Walker MP, et al:: Chemical/molecular structure of the dentinenamel junction is dependent on the intratooth location. Calcif Tissue Int. 2009 84(3): 221-228.

PubMed Abstract | Publisher Full Text | Free Full Text

7. Moradian-Oldak J: The regeneration of tooth enamel. Dimens Dent Hyg. 2009; 7(8): $12-15$.

PubMed Abstract | Free Full Text

8. Palmer LC, Newcomb CJ, Kaltz SR, et al: Biomimetic systems for hydroxyapatite mineralization inspired by bone and enamel. Chem Rev. 2008 ; 108(11): 4754-4783.

PubMed Abstract | Publisher Full Text | Free Full Text

9. Bartlett JD: Dental enamel development: proteinases and their enamel matrix substrates. ISRN Dent. 2013; 2013: 684607.

PubMed Abstract | Publisher Full Text | Free Full Text

10. Moradian-Oldak J: Protein-mediated enamel mineralization. Front Biosci (Landmark Ed). 2012; 17: 1996-2023.

PubMed Abstract | Publisher Full Text | Free Full Text

11. Bei M: Molecular genetics of ameloblast cell lineage. J Exp Zool B Mol Dev Evol. 2009; 312B(5): 437-444.

PubMed Abstract | Publisher Full Text | Free Full Text
12. Simmer JP Papagerakis $P$, Smith $C E$, et al: Regulation of dental enamel shape and hardness. J Dent Res. 2010; 89(10): 1024-1038.

PubMed Abstract | Publisher Full Text | Free Full Text

13. Smith CE, Nanci A: Protein dynamics of amelogenesis. Anat Rec. 1996; 245(2): 186-207.

PubMed Abstract | Publisher Full Text

14. Habelitz S: Materials engineering by ameloblasts. J Dent Res. 2015; 94(6): $759-767$.

PubMed Abstract | Publisher Full Text | Free Full Text

15. Ali S, Farooq I: A Review of the role of amelogenin protein in enamel formation and novel experimental techniques to study its function. Protein Pept Lett. 2019; 26(12): 880-886.

PubMed Abstract | Publisher Full Text

16. Smith $\mathrm{CE}$, Wazen $\mathrm{R}, \mathrm{Hu} \mathrm{Y}$, et al:: Consequences for enamel development and mineralization resulting from loss of function of ameloblastin or enamelin. Eur J Oral Sci. 2009; 117(5): 485-497.

PubMed Abstract | Publisher Full Text | Free Full Text

17. Fava M: Prismless enamel in human non-erupted deciduous molar teeth: $\mathbf{A}$ scanning electron microscopic study. Rev Odontol Univ Sao Paulo. 1997; 11(4): 239-43.

Publisher Full Text

18. Farooq I, Majeed A, AIShwaimi E, et al.: Efficacy of a novel fluoride containing bioactive glass based dentifrice in remineralizing artificially induced demineralization in human enamel. Fluoride. 2019; 52(3 Pt 3): 447-455. Reference Source

19. Aoba T: The effect of fluoride on apatite structure and growth. Crit Rev Oral Biol Med. 1997; 8(2): 136-153 PubMled Abstract | Publisher Full Text

20. Featherstone JDB, Lussi A: Understanding the chemistry of dental erosion. Monogr Oral Sci. 2006; 20: 66-76. PubMed Abstract | Publisher Full Text

21. Boanini $E$, Gazzano M, Bigi A: lonic substitutions in calcium phosphates synthesized at low temperature. Acta Biomater. 2010; 6(6): 1882-1894. PubMed Abstract | Publisher Full Text

22. Müller F, Zeitz C, Mantz $\mathrm{H}$, et al.: Elemental depth profiling of fluoridated hydroxyapatite: saving your dentition by the skin of your teeth? Langmuir. 
2010; 26(24): 18750-18759.

PubMed Abstract | Publisher Full Text

23. Karasek $\mathrm{M}$, Woldanska-Okonska M: Electromagnetic fields and human endocrine system. Sci World J. 2004; 4 Suppl 2: 23-28.

PubMed Abstract | Publisher Full Text | Free Full Text

24. Parul: Human endocrine system: A secreting organ or structure. J Med Plant Stud. 2015; 3(6): 118-123.

Reference Source

25. Holmberg KV, Hoffman MP: Anatomy, biogenesis and regeneration of salivary glands. Monogr Oral Sci. 2014; 24: 1-13.

PubMed Abstract | Publisher Full Text | Free Full Text

26. Togni L, Mascitti M, Santarelli A, et al:: Unusual Conditions Impairing Saliva Secretion: Developmental Anomalies of Salivary Glands. Front Physiol. 2019; 10: 855 .

PubMed Abstract | Publisher Full Text | Free Full Text

27. Samiei M, Ahmadian E, Eftekhari A, et al.: Cell junctions and oral health. Excli J. 2019; 18: 317-330

PubMed Abstract | Publisher Full Text | Free Full Text

28. de Paula F, Teshima THN, Hsieh R, et al: Overview of Human Salivary Glands: Highlights of Morphology and Developing Processes. Anat Rec (Hoboken). 2017; 300(7): 1180-1188

PubMed Abstract | Publisher Full Text

29. Hand AR, Pathmanathan D, Field RB: Morphological features of the minor salivary glands. Arch Oral Biol. 1999; 44 Suppl 1: S3-S10.

PubMed Abstract | Publisher Full Text

30. Faran Ali SM, Tanwir F: Oral microbial habitat a dynamic entity. J Oral Biol Craniofac Res. 2012; 2(3): 181-187.

PubMed Abstract | Publisher Full Text | Free Full Text

31. Kumar B, Kashyap N, Avinash A, et al:: The composition, function and role of saliva in maintaining oral health: a review. Int J Contemp Dent Med Rev. 2017; 011217: $1-6$

Reference Source

32. Palaghias G: The role of phosphate and carbonic acid-bicarbonate buffers in the corrosion processes of the oral cavity. Dent Mater. 1985; 1(4): 139-144. PubMed Abstract | Publisher Full Text

33. Hicks J, Garcia-Godoy F, Flaitz C: Biological factors in dental caries: role of saliva and dental plaque in the dynamic process of demineralization and remineralization (part 1). J Clin Pediatr Dent. 2003; 28(1): 47-52.

PubMed Abstract | Publisher Full Text

34. Hegde MN, Sajnani AR: Salivary Proteins-A Barrier on Enamel Demineralization: An in vitro Study. Int J Clin Pediatr Dent. 2017; 10(1): 10-13. PubMed Abstract | Publisher Full Text | Free Full Text

35. Hemadi AS, Huang R, Zhou Y, et al.: Salivary proteins and microbiota as biomarkers for early childhood caries risk assessment. Int J Oral Sci. 2017; 9(11): e1.

PubMed Abstract | Publisher Full Text | Free Full Text

36. Schenkels LC, Veerman EC, Nieuw Amerongen AV: Biochemical composition of human saliva in relation to other mucosal fluids. Crit Rev Oral Biol. 1995; 6(2): $161-75$

PubMed Abstract | Publisher Full Text

37. Moslemi M, Sattari M, Kooshki F, et al:: Relationship of Salivary Lactoferrin and Lysozyme Concentrations with Early Childhood Caries. J Dent Res Dent Clin Dent Prospects. 2015; 9(2): 109-114.

PubMed Abstract | Publisher Full Text | Free Full Text

38. Lenander-Lumikari M, Loimaranta V: Saliva and dental caries. Adv Dent Res. 2000; 14: 40-47.

PubMed Abstract | Publisher Full Text

39. Dawes $\mathrm{C}$ : What is the critical $\mathrm{pH}$ and why does a tooth dissolve in acid? $\mathrm{J}$ Can Dent Assoc. 2003; 69(11): 722-724.

PubMed Abstract

40. Ali S, Farooq I, Al-Thobity AM, et al:: An in-vitro evaluation of fluoride content and enamel remineralization potential of two toothpastes containing different bioactive glasses. Biomed Mater Eng. 2019; 30(5-6): 487-496.

PubMed Abstract | Publisher Full Tex

41. Pajor K, Pajchel L, Kolmas J: Hydroxyapatite and Fluorapatite in Conservative Dentistry and Oral Implantology-A Review. Materials (Basel). 2019; 12(17) pii: E2683.

PubMed Abstract | Publisher Full Text | Free Full Text

42. Talwar M, Borzabadi-Farahani A, Lynch E, et al.: Remineralization of Demineralized Enamel and Dentine Using 3 Dentifrices-An InVitro Study. Dent J (Basel). 2019; 7(3): pii: E91.

PubMed Abstract | Publisher Full Text | Free Full Tex

43. Lynch RJ, Navada R, Walia R: Low-levels of fluoride in plaque and saliva and their effects on the demineralisation and remineralisation of enamel; role of fluoride toothpastes. Int Dent J. 2004; 54(5 Suppl 1): 304-309. PubMed Abstract | Publisher Full Text
44. Edgar WM, Higham SM: Role of saliva in caries models. Adv Dent Res. 1995 9(3): 235-238.

PubMed Abstract | Publisher Full Text

45. Dai Z, Liu M, Ma Y, et al.: Effects of Fluoride and Calcium Phosphate Materials on Remineralization of Mild and Severe White Spot Lesions. Biomed Res Int. 2019; 2019: 1271523.

PubMed Abstract | Publisher Full Text | Free Full Text

46. Meyer F, Amaechi BT, Fabritius HO, et al: Overview of Calcium Phosphates used in Biomimetic Oral Care. Open Dent J. 2018; 12: 406-423. PubMed Abstract | Publisher Full Text | Free Full Text

47. Zhao J, Liu Y, Sun WB, et al.: Amorphous calcium phosphate and its application in dentistry. Chem Cent $J$. 2011: 5: 40. PubMed Abstract | Publisher Full Text | Free Full Text

48. Arifa MK, Ephraim R, Rajamani T: Recent Advances in Dental Hard Tissue Remineralization: A Review of Literature. Int J Clin Pediatr Dent. 2019; 12(2): $139-144$.

PubMed Abstract | Publisher Full Text | Free Full Text

49. Hannig M: Ultrastructural investigation of pellicle morphogenesis at two different intraoral sites during a 24-h period. Clin Oral Investig. 1999; 3(2): 88-95.

PubMed Abstract | Publisher Full Text

50. Hannig M, Hannig C: The pellicle and erosion. Monogr Oral Sci. 2014; 25: 206-214. PubMed Abstract | Publisher Full Text

51. Baumann $T$, Bereiter R, Lussi A, et al:: The effect of different salivary calcium concentrations on the erosion protection conferred by the salivary pellicle. Sci Rep. 2017; 7(1): 12999

PubMed Abstract | Publisher Full Text | Free Full Text

52. Cummins D: The development and validation of a new technology, based upon $1.5 \%$ arginine, an insoluble calcium compound and fluoride, for everyday use in the prevention and treatment of dental caries. J Dent. 2013; 41(Suppl 2): S1-S11.

PubMed Abstract | Publisher Full Text

53. Philip N: State of the Art Enamel Remineralization Systems: The Next Frontie in Caries Management. Caries Res. 2019; 53(3): 284-295. PubMed Abstract | Publisher Full Text | Free Full Text

54. Prasad M, Butler WT, Qin C: Dentin sialophosphoprotein in biomineralization Connect Tissue Res. 2010; 51(5): 404-417. PubMed Abstract | Publisher Full Text | Free Full Text

55. Yarbrough DK, Hagerman E, Eckert R, et al.: Specific binding and mineralization of calcified surfaces by small peptides. Calcif Tissue Int. 2010; 86(1): 58-66. PubMed Abstract | Publisher Full Text | Free Full Text

56. Ruan Q, Moradian-Oldak J: Amelogenin and Enamel Biomimetics. J Mater Chem B. 2015; 3: 3112-3129.

PubMed Abstract | Publisher Full Text | Free Full Text

57. Fan $\mathrm{Y}$, Sun Z, Moradian-Oldak J: Controlled remineralization of enamel in the presence of amelogenin and fluoride. Biomaterials. 2009; 30(4): 478-483. PubMed Abstract | Publisher Full Text | Free Full Text

58. Le Norcy E, Kwak SY, Wiedemann-Bidlack FB, et al:: Leucine-rich amelogenin peptides regulate mineralization in vitro. J Dent Res. 2011; 90(9): 1091-1097. PubMed Abstract | Publisher Full Text | Free Full Text

59. Pepla E, Besharat LK, Palaia G, et al:: Nano-hydroxyapatite and its applications in preventive, restorative and regenerative dentistry: a review of literature. Ann Stomatol (Roma). 2014; 5(3): 108-114. PubMed Abstract | Publisher Full Text | Free Full Text

60. Farooq I, Moheet I, Imran Z, et al:: A Review of Novel Dental Caries Preventive Material: Casein Phosphopeptide-Amorphous Calcium Phosphate (CPP-ACP) Complex. King Saud Uni J Dent Sci. 2013; 4(2): 47-51. Publisher Full Text

61. Reynolds EC: Casein phosphopeptide-amorphous calcium phosphate: the cientific evidence. Adv Dent Res. 2009; 21(1): 25-29. PubMed Abstract | Publisher Full Text

62. Alhussain AM, Alhaddad AA, Ghazwi MM, et al:: Remineralization of artificial carious lesions using a novel fluoride incorporated bioactive glass dentifrice. Dent Med Probl. 2018; 55(4): 379-382. PubMed Abstract | Publisher Full Text

63. Burwell AK, Litkowski LJ, Greenspan DC: Calcium sodium phosphosilicate (NovaMin): remineralization potential. Adv Dent Res. 2009; 21(1): 35-39. PubMed Abstract | Publisher Full Text

64. Freire IR, Pessan JP, Amaral JG, et al.: Anticaries effect of low-fluoride dentifrices with phosphates in children: a randomized, controlled trial. $J$ Dent. 2016; 50: 37-42.

PubMed Abstract | Publisher Full Text

65. Faroog I, Ali S, Siddiqui IA, et al:: Influence of Thymoquinone Exposure on the Micro-Hardness of Dental Enamel: An In Vitro Study. Eur J Dent. 2019; 13(3): 318-322.

PubMed Abstract | Publisher Full Text 


\section{Open Peer Review}

\section{Current Peer Review Status:}

\section{Version 1}

Reviewer Report 25 March 2020

https://doi.org/10.5256/f1000research.24830.r61099

(C) 2020 Kazmi D. This is an open access peer review report distributed under the terms of the Creative Commons Attribution License, which permits unrestricted use, distribution, and reproduction in any medium, provided the original work is properly cited.

\section{Dr. Shakeel Abbas Kazmi}

Dundee Dental School, University of Dundee, Dundee, UK

It is a well-written article. The role of salivary contents are comprehensively explained. I would like to suggest the following suggestions:

1. The inclusion criteria of the articles is a bit confusing. How the research started is wellwritten but later it is a bit confusing how 500 relevant articles were selected. It would be nice to know how these 500 articles were selected.

2. Some flow charts, for the selection of the articles for research can be helpful.

3. Similarly, if there could be a chart, diagram or table before the conclusion, it would help in learning about the article summary.

Is the topic of the review discussed comprehensively in the context of the current literature?

Yes

Are all factual statements correct and adequately supported by citations?

Yes

Is the review written in accessible language?

Yes

Are the conclusions drawn appropriate in the context of the current research literature? Yes

Competing Interests: No competing interests were disclosed.

I confirm that I have read this submission and believe that I have an appropriate level of expertise to confirm that it is of an acceptable scientific standard. 
Author Response 27 Mar 2020

Imran Farooq, College of Dentistry, Imam Abdulrahman Bin Faisal University, Dammam, Saudi Arabia

Thank you for your comments and accepting our article. We have revised the article as per your suggestions.

1) We have added a flow chart depicting search strategy involved in this article. We hope this will answer your concern.

2) A flow chart has been added as per your suggestion.

3) Instead of a chart, we have added a micro-CT figure which shows remineralization of enamel surface.

Competing Interests: None

Reviewer Report 16 March 2020

https://doi.org/10.5256/f1000research.24830.r61100

(C) 2020 Raj A. This is an open access peer review report distributed under the terms of the Creative Commons Attribution License, which permits unrestricted use, distribution, and reproduction in any medium, provided the original work is properly cited.

\section{A. Thirumal Raj}

Department of Oral Pathology and Microbiology, Sri Venkateswara Dental College and Hospital, Chennai, Tamil Nadu, India

It is a well executed review. There are a few suggestions which could improve the overall impact of the review:

1. Adding a schematic summarizing the de-mineralization and re-mineralization of dental enamel would improve the overall impact of the article.

2. Was this a systematic review? If not mention that it is a narrative review based on published literature.

3. A table summarizing the various recent techniques in re-mineralization along with each of their advantages and limitations would be vital for the article.

4. The article seems to end abruptly. Kindly add a couple of sentences on prospects of further research as the concluding sentence.

The above-mentioned corrections are just suggestions to improve the overall quality of the article. I recommend the authors consider implementing the recommendations. 
Is the topic of the review discussed comprehensively in the context of the current literature?

Yes

Are all factual statements correct and adequately supported by citations?

Yes

Is the review written in accessible language?

Yes

Are the conclusions drawn appropriate in the context of the current research literature? Yes

Competing Interests: No competing interests were disclosed.

Reviewer Expertise: Oral pathology and microbiology

I confirm that I have read this submission and believe that I have an appropriate level of expertise to confirm that it is of an acceptable scientific standard.

Author Response 27 Mar 2020

Imran Farooq, College of Dentistry, Imam Abdulrahman Bin Faisal University, Dammam, Saudi Arabia

Thank you for your comments and accepting our article. We have revised the article as per your suggestions.

1) We have added a micro-CT image which shows remineralization of enamel's surface.

2) We have now added the word "narrative" to the title.

3) This would be part of our next paper which would be dealing with this point.

4) We have added few sentences to answer your concern.

Competing Interests: None

Reviewer Report 13 March 2020

https://doi.org/10.5256/f1000research.24830.r61101

(C) 2020 Ullah R. This is an open access peer review report distributed under the terms of the Creative Commons Attribution License, which permits unrestricted use, distribution, and reproduction in any medium, provided the original work is properly cited. 


\section{Rizwan Ullah}

Department of Oral Biology, Sindh Institute of Oral Health Sciences, Jinnah Sindh Medical

University, Karachi, Pakistan

I have the following comments and suggestions for the authors:

1. What is the reason for choosing 35 years and two databases Google Scholar and PubMed? As some of the studies that may be some important papers published in journals indexed in other databases will be missing.

2. Present complete article search and selection process in a flow chart outlining the exclusion of articles at each stage. In methodology give a brief account how it was decided to include or exclude an article.

3. Kindly rephrase the sentence on Page 2. " Only after the advent of modern techniques using transmission and scanning electron microscopy, was the more complex structure of enamel revealed".

4. Kindly rephrase the students on Page 3 "The breakdown of proteins by bacterial originated urease to urea and ammonia aids plays a role in maintaining a neutral $\mathrm{pH}$ in oral cavity"

Is the topic of the review discussed comprehensively in the context of the current literature?

Yes

Are all factual statements correct and adequately supported by citations?

Yes

Is the review written in accessible language?

Yes

Are the conclusions drawn appropriate in the context of the current research literature? Yes

Competing Interests: No competing interests were disclosed.

I confirm that I have read this submission and believe that I have an appropriate level of expertise to confirm that it is of an acceptable scientific standard.

Author Response 27 Mar 2020

Imran Farooq, College of Dentistry, Imam Abdulrahman Bin Faisal University, Dammam, Saudi Arabia

Thank you for your comments and accepting our article. We have revised the article as per your suggestions.

1) Many journals now consider references which are 10 years old outdated. We kept a 
bigger window for our article and this is the reason we did not include any reference which was published more than 35 years ago. To make sure we don't miss any important studies, we chose two databases instead of one.

2) A flow chart has now been added which depicts the search strategy involved in this study.

3) This sentence has been rephrased.

4) We believe the sentence is clear and unfortunately, rephrasing it would make it unclear.

Competing Interests: None

The benefits of publishing with F1000Research:

- Your article is published within days, with no editorial bias

- You can publish traditional articles, null/negative results, case reports, data notes and more

- The peer review process is transparent and collaborative

- Your article is indexed in PubMed after passing peer review

- Dedicated customer support at every stage

For pre-submission enquiries, contact research@f1000.com 